\title{
Gonadotropin-Releasing Hormone Receptor
}

National Cancer Institute

\section{Source}

National Cancer Institute. Gonadotropin-Releasing Hormone Receptor. NCI Thesaurus.

Code C38910.

Gonadotropin-releasing hormone receptor (328 aa, $~ 38 \mathrm{kDa}$ ) is encoded by the human GNRHR gene. This protein is involved in the regulation of pituitary hormone release and G protein-coupled receptor signaling. 